\title{
MEMBUMIKAN IDEOLOGI PANCASILA MELALUI PENDIDIKAN PANCASILA SEBAGAI UPAYA MEMBANGKITKAN NASIONALISME
}

\author{
Abdul Malik \\ Dosen Fakultas Ekonomi Universitas Muslim Nusantara Medan \\ Abdulmaliknst28@Gmail.Com
}

\begin{abstract}
Abstrak
Pancasila Sebagai Ideologi Bangsa Dan Negara Indonesia, Pascareformasi Tahun 1998, Seperti Barang Usang Yang Tidak Diperdulikan, Padahal Berisikan Norma-Norma Moral Yang Diambil Dari Kearifan Lokal Yang Ada Di Indonesia. Namun Dalam Beberapa Tahun Belakangan Ini Muncul Kembali Kesadaran Untuk Mengembalikan Pancasila Sebagai Norma Moral. Hal Ini Dilakukan Karena Melihat Sebagian Besar Warga Negara Indonesia Kehilangan Jati Dirinya Sebagai Bangsa Indonesia. Banyaknya Kasus-Kasus Asusila, Para Pejabat Yang Korupsi, Hilangnya Sifat Gotong Royong Yang Menjadi Ciri Khas Rakyat Indonesia, Perpecahan Antaranak Bangsa, Mengindikasikan Bahwa Pancasila Sebagai Ideologi Mulai Ditinggalkan. Oleh Karena Itu Diperlukan Metode Khusus Untuk Mengembalikan Pancasila Kembali Kepada Tempatnya Semula. Mengadakan Lagi Mata Pelajaran Atau Mata Kuliah Pendidikan Pancasila, Diyakini Sebagai Formula Tepat Untuk Mengembalikan Jati Diri Bangsa Indonesia Yang Tercabik Akibat Arus Globalisasi.
\end{abstract}

Kata Kunci: Ideologi, Pancasila, Pendidikan, Nasionalisme

\section{PENDAHULUAN}

Secara Historis, Pancasila Lahir Sebagai Ideologi Bangsa Yang Diambil Dari Nilai-Nilai Kearifan Lokal Yang Tumbuh Dan Kembang Di Indonesia. Perspektif Historis Menyatakan Bahwa Nilai-Nilai Dari Pancasila Sudah Diterapkan Di Kalangan Masyarakat Indonesia Sebelum Berdirinya Berbagai Kerajaan Besar Di Indonesia, Misalnya Kerajaan Sriwijaya Di Sumatera Pada Abad ViiXii Dan Kerajaan Majapahit Di Jawa Timur Pada Abad Xii-Xvi. Aktualisasi Nilai-Nilai Tersebut Antara Lain Dengan Adanya Kepercayaan Terhadap Hal-Hal Ghaib, Pemujaan Terhadap Roh-Roh Dengan Model Dinamisme Maupun Animisme, Masyarakat Yang Gemar Tolong-Menolong, Menjaga Rasa Aman, Dan Sebagainya. (Marsudi, 2008: 1)

Pascareformasi Tahun 1998, Dengan

Tameng Reformasi, Pancasila Sepertinya "Sudah Ditinggalkan", Karena Dianggap Produk Orde Lama Dan Orde Baru. Pancasila Sebagai Ideologi Bangsa Bahkan Beberapa Kali Coba Untuk Diubah Dengan Idoelogi Lain, Yang Belum Tentu Sesuai Dengan Kondisi Sosial Dan Budaya Indonesia. Kemudian Apabila Dilihat Dari Sisi Kehidupan Berbangsa Dan Bernegara, Hari Ini Ditemukan Bahwa Nilai-Nilai Moral Yang Melekat Dalam Pancasila Sebagai Jati Diri Bangsa Sudah Mulai Luntur, Karena Gencarnya Pengaruh Teknologi Dan Budaya Yang Berasal Dari Luar Indonesia.

Pancasila Sebagai Ideologi Bangsa Dipastikan Akan Terus Mengalami Hambatan, Tantangan Baik Yang Datangnya Dari Internal Maupun Eksternal. Pancasila, Secara Internal Akan Terus Berhadapan Dengan Pemikiran
Ekstrimisme Yang Pasti Tidak Menghormati Pluralisme Yang Menjadi Ciri Bangsa Indonesia, Dan Secara Eksternal Tanpa Disadari, Pancasila Cenderung Termarginalkan Dari Sisi Kehidupan Masyarakat Antar Bangsa, Khususnya Dengan Berlakunya Standar-Standar Yang Sifatnya Universal, Dimana Pancasila Dianggap Sebagai Suatu Elemen Partikularistik Yang Menolak Nilai-Nilai Universal Secara Keseluruhan. (Muladi, 2006: 3)

Berdasarkan Fakta Tersebut, Maka Sangat Urgen Untuk Mengembalikan Pancasila Sebagai Dasar Atau Pedoman Berbangsa Dan Bernegara, Agar Bibit-Bibit Keretakan Yang Akan Menghilangkan Jati Diri Bangsa Serta Berkurangnya Rasa Nasionalisme Dapat Diminimalisir. Oleh Karena Itu Diperlukan Kesadaran Secara Kolektif Untuk Membumikan Pancasila Sebagai Ideologi Bangsa Dengan Mengembalikan Pendidikan Pancasila Sebagai Sebuah Mata Pelajaran Sejak Dari Sekolah Tingkat Paling Bawah Sampai Dengan Jenjang Perguruan Tinggi.

\section{METODE PENELITIAN}

Sejarah Lahirnya Pancasila Sebagai Ideologi Bangsa

Sebagai Ideologi Bangsa Indonesia, Pancasila Lahir Bukan Tanpa Akar Sejarah Yang Kuat. Banyak Unsur Yang Terkandung Dalam Nilai-Nilai Luhur Yang Lahir Dari ButirButir Dari Lima Sila Yang Terdapat Dalam Pancasila. Kata Pancasila Secara Etimologis Berasal Dari Bahasa Sansekerta, Yang Merupakan Gabungan Dua Kata, Yaitu Panca Yang Artinya Lima, Sedangkan Sila Bermakna Dasar. Kata "Sila" Dimaknai Sebagai Aturan 
Dasar Yang Melatarbelakangi Perbuatan Seseorang Maupun Bangsa Sesuai Dengan Adab Dan Moral. (Febriansyah, 2016: 16)

Secara Terminologi, Pancasila Adalah Dasar Negara Republik Indonesia. Digunakannya Kata Pancasila Sebagai Suatu Istilah Pertama Kali Diperkenalkan Oleh Soekarno, Ketika Berpidato Di Hadapan Sidang Pada Hari Ketiga Badan Penyelidik UsahaUsaha Persiapan Kemerdekaan Indonesia (Bpupki). Dalam Pidatonya Tersebut, Soekarno Mengusukan Lima Hal Untuk Kemudian Menjadi Dasar Negara Indonesia Merdeka Dan Memberi Nama Pancasila. (Rosyadi, 2008: 186) Istilah Pancasila Sebenarnya Bukanlah Sesuatu Yang Asing Bagi Bangsa Indonesia, Karena Pada Zaman Kerajaan Majapahit, Pancasila Telah Digunakan Sebagai Pijakan Moral Hidup Bangsa Indonesia. Manuskrip Tentang Nilai-Nilai Pancasila Tersebut Telah Tercantum Dalam Kitab Negara Kertagama Yang Ditulis Oleh Empu Prapanca Serta Dalam Kitab Sutasoma Yang Ditulis Oleh Empu Tantular. Dalam Kitab Sutasoma Terdapat Pancasila Krama (Lima Dasar Tingkah Laku Atau Perintah Kesusilaan), Yang Terdiri Dari:

a) Tidak Boleh Melakukan Kekerasan (Ahimsi),

b) Tidak Boleh Mencuri (Asteya),

c) Tidak Boleh Berbuat Dengki (Indiya Nugraha),

d) Tidak Boleh Melakukan Kebohongan (Amisawada),

e) Tidak Boleh Meminum Minuman Keras (Dama).

Selain Lima Dasar Moral Di Atas, Terdapat Dalam Kitab Sutasoma Adanya Semboyan Bhinneka Tunggal Ikatan Hana Dharma Mangruwa Yang Mempunyai Arti, Walaupun Agama Itu Mempunyai Perbedaan Baik Bentuk Maupun Sifatnya, Akan Tetapi Pada Hakikatnya Satu Juga. Semboyan Ini Pula Yang Pada Periode Ratusan Tahun Selanjutnya Menjadi Semboyan Lambang Negara Indonesia, Yaitu Bhinneka Tunggal Ika. (Marsudi, 2008: 2)

Menurut Doreoso, Ada Beberapa Kategorisasi Terkait Dengan Sejarah Perumusan Pancasila, Yang Dikemukakan Oleh Beberapa Tokoh, Yaitu:

a. Rumusan Dari Moh. Yamin Yang Disampaikan Secara Lisan Pada 29 Mei 1945 Yang Berisi Peri Kebangsaan, Peri Kemanusiaan, Peri Ketuhanan, Peri Kerakyatan, Dan Kesejahteraan Sosial (Keadilan Sosial). M. Yamin Sendiri Tidak Memberikan Nama Terhadap Usulannya Tersebut.

b. Moh. Yamin Sebagaimana Diungkapkan Dalam Tulisan Yang Berisi Ketuhanan Yang Maha Esa,
Kebangsaan Persatuan Indonesia, Rasa Kemanusiaan Yang Adil Dan Beradab, Kerakyatan Yang Dipimpin Oleh Hikmat Kebijaksanaan Dalam Permusyawaratan Perwakilan, Dan Keadilan Sosial Bagi Seluruh Rakyat Indonesia.

c. Ir. Soekarno Yang Menyampaikan Gagasannya Pada Tanggal 1 Juni 1945 Dengan Nama Pancasila Yang Didalamnya Berisi Kebangsaan Indonesia, Internasionalisme Dan Kemanusiaan, Mufakat Atau Demokrasi, Kesejahteraan Sosial, Dan Ketuhanan Yang Berkebudayaan.

d. Rumusan Dari Panitia Sembilan/Piagam Jakarta 22 Juni 1945, Yang Berisi Tentang Ketuhanan Dengan Kewajiban Menjalankan Syari'at Islam Bagi PemelukPemeluknya, Kemanusiaan Yang Adil Dan Beradab, Persatuan Indonesia, Kerakyatan Yang Dipimpin Oleh Hikmat Kebijaksanaan Dalam Permusyawaratan Perwakilan, Dan Keadilan Sosial Bagi Seluruh Rakyat Indonesia.

e. Rumusan Oleh Ppki/Pembukaan Uud 1945 Tanggal 18 Agustus 1945, Yang Berisi Ketuhanan Yang Maha Esa, Kemanusiaan Yang Adil Dan Beradab, Persatuan Indonesia, Kerakyatan Yang Dipimpin Oleh Hikmat Kebijaksanaan Dalam Permusyawaratan Perwakilan, Dan Keadilan Sosial Bagi Seluruh Rakyat Indonesia.

f. Rumusan Yang Berasal Dari Panitia Ketatanegaraan/Konstitusi Ris Pada Tanggal 27 Desember 1949 Sama Dengan Panitia Bersama Uuds 1950 Pada 17 Agustus 1950 Berisi Mengenai Ketuhanan Yang Maha Esa, Peri Kemanusiaan, Kebangsaan, Kedaulatan Rakyat, Dan Keadilan Sosial. (1989: 123-124)

g. Mr. Soepomo Menyampaikan 5 (Lima) Usulan Calon Dasar Negara Yang Terdiri Dari: 1) Nasionalisme/Internasionalisme; 2) Takluk Kepada Tuhan; 3) Kerakyatan; 4) Kekeluarggaan; 5) Keadilan Rakyat. Mr. Soepomo, Juga Belum Memberikan Nama Terhadap 5 Usulan Rancangan Calon Dasar Negara. (Brata, 2017: 128)

Sidang-Sidang Yang Dilakukan Oleh Panitia Persiapan Kemerdekaan Indonesia Pada Tanggal 18, 19, 20, Dan 22 Agustus 1945, Setelah Indonesia Merdeka 17 Agustus 1945, Telah Membuat Sejumlah Keputusan. 
Keputusan Pertama Dan Terpenting Adalah Pengesahan Pembukaan Undang-Undang Dasar Negara Republik Indonesia Tahun 1945, Yang Di Dalamnya Terdapat Rumusan Dasar Negara Pancasila.

Konsep Pancasila Sebagai Dasar Negara Sendiri Diajukan Oleh Ir. Soekarno Dalam Sebuah Pidatonya Di Hari Terakhir Sidang Pertama Bpupki Tanggal 1 Juni 1945, Yang Isinya Untuk Menjadikan Pancasila Sebagai Dasar Negara, Falsafah Negara Atau Filosophische Grondslag Bagi Negara Indonesia Merdeka. Usulan Tersebut Ternyata Dapat Diterima Oleh Seluruh Anggota Sidang. Istilah Pancasila Sendiri Berasal Dari Atau Mengacu Kepada Materi Rapat Besar Bpuki Tanggal 1 Juni 1945 Yang Saat Itu Dalam Sidang Resmi. Bpupki Tersebut Kemudian Diintroduksi Suatu Istilah Bahasa Indonesia Yang Semua Berasal Dari Bahasa Sansekerta, Yaitu Pancasila. Kata Pancasila Terlontar Dan Kemudian Mencuat Ke Permukaan Dalam Konteks Sebuah Nama Untuk Nama Dasar Negara Indonesia Merdeka Di Wilayah Nusantara Yang Pada Masa Itu Sedang Dicari Dan Dgali Dari Budaya (Kultur) Yang Bhineka Bangsa Indonesia Sendiri Oleh Para Pendiri Negara Indonesia. Rumusannya Secara Yuridis Konstitusional Dimaksudkan Seperti Yang Tercantum Dalam Pembukaan Undang-Undang Dasar Negara Republik Indonesia Tahun 1945 Tadi. (Riyanto, 2007: 465)

Oleh Karena Rumusan Pancasila Tersebut Terdapat Dalam Pembukaan UndangUndang Dasar Negara Republik Indonesia Tahun 1945, Undang-Undang Dasar Tersebut Sebagai Hukum Tertinggi Yang Tidak Dapat Diubah Secara Hukum, Maka Pancasila Sebagai Dasar Negara Indonesia Bersifat Final Dan Mengikat Bagi Seluruh Lembaga Negara Beserta Lembaga Subdivisinya, Organisasi Kemasyarakatan, Kelompok, Dan Perseorangan Warga Negara Indonesia. (Riyanto, 2007: 465)

Penetapan Pancasila Sebagai Dasar Negara Itu Memberikan Pengertian Bahwa Negara Indonesia Adalah Negara Pancasila. Hal Tersebut Mengandung Arti Bahwa Negara Harus Tunduk Kepadanya, Membela Dan Melaksanakannya Dalam Keseluruhan Perundang-Undangan Yang Ditetapkan Di Indonesia. Mengenai Hal Itu "Negara Pancasila Adalah Suatu Negara Yang Didirikan, Dipertahankan Serta Dikembangkan Dengan Tujuan Untuk Melindungi Dan Mengembangkan Martabat Serta Hak Asasi Manusia Seluruh Warga Bangsa Indonesia (Sila Kemanusiaan Yang Adil Dan Beradab) Agar Masing-Masing Dapat Hidup Layak Sebagai Manusia, Mengembangkan Dirinya Dan
Mewujudka Kesejahteraan Umum, Yakni Kesejahteraan Lahir Batin Seluruh Rakyat Dan Dapat Hidup Secara Layak Sebagai Manusia, Mengembangkan Dirinya Dan Mewujudkan Kesejahteraan Umum, Yaitu Kesejahteraan Lahir Batin Seluruh Rakyat, Serta Mencerdaskan Kehidupan Bangsa (Keadilan Sosial).

\section{HASIL DAN PEMBAHASAN PENELITIAN \\ Pancasila Sebagai Ideologi Bangsa}

Setiap Negara Pasti Memiliki Ideologinya Masing-Masing. Dalam Kehidupan Bernegara, Ideologi Diartikan Sebagai Suatu Konsensus Mayoritas Tentang Nilai-Nilai Dasar Yang Ingin Diujudkan Dengan Mendirikan Negara, Yang Dalam Hal Ini Disebut Juga Sebagai Philoofische Grondslag Atau Weltanschuung Yang Merupakan PikiranPikiran Terdalam, Hasrat Terdalam Warga Negaranya, Untuk Diatasnya Didirikan Suatu Negara. (Suryatni, 2014: 35)

Secara Harfiah, Ideologi Berarti $A$ System Of Ideas, Akan Mensistematisasikan Seluruh Pemikiran Mengenai Kehidupan Ini, Dan Melengkapinya Dengan Sarana Serta Kebijakan Dan Strategi, Dengan Tujuan Menyesuaikan Keadaan Nyata Dengan NilaiNilai Yang Terkandung Dalam Filsafat Yang Menjadi Induknya. Artinya Bahwa Ideologi Adalah Petunjuk Pelaksanaan Bagi Filsafat. (Supriyatno, 2011: 165)

Magnis-Suseno, Menyatakan Arti Ideologi Secara Umum Ada Tiga, Pertama, Ideologi Sebagai Kesadaran Palsu, Kedua, Ideologi Dalam Arti Netral; Dan Ketiga Ideologi Dalam Arti Keyakinan Yang Tidak Ilmiah. (1992: 230). Pancasila Dalam Arti Kesadaran Palsu Menjelaskan Bahwa Ideologi Digunakan Agar Masyarakat Mengakui Dan Meyakini Tentang Keyakinan Yang Dimiliki Oleh Seseorang. Ideologi Dalam Hal Ini Lazim Dipahami Tentang Berbagai Teori Yang Tidak Berorientasi Pada Kebenaran Melainkan Pada Kepentingan Pihak Yang Memprogandakannya Atau Yang Dapat Disebut Dengan Melegalkan Sistem Kekuasaan Yang Dipegang Oleh Seseorang. Ideologi Dalam Arti Netral Diartikan Sebagai Keseluruhan Sistem Berfikir, Nilai-Nilai, Dan Sikap Dasar Suatu Kelompok Sosial Atau Kebudayaan Tertentu. Arti Netral Disini Karena Baik Buruknya Tergantung Kepada Isi Ideologi Tersebut. Ideologi Dalam Arti Keyakinan Yang Tidak Ilmiah, Lazimnya Digunakan Dalam Filsafat Dan Ilmu-Ilmu Sosial Yang Sifatnya Positivistik, Yaitu Segala Macam Pemikiran Yang Tidak Dapat Dibuktikan Secara Logis, Matematis Atau Empiris. (Sutrisno, 2016: 42) 
Ideologi Bagi Sebuah Negara Sangatlah Penting. Hal Ini Disebabkan Bahwa Ideologi Yang Dianut Diyakini Akan Membawa Negara-Bangsa Kearah Kemakmuran Dan Keadilan. (Kassab, 2016: 2-9). Hal Yang Sama Diutarakan Oleh Soekarno Dalam Pidatonya Saat Sidang Perumusan Pancasila Tanggal 1 Juni 1945:

"Saya Di Dalam 3 Hari Ini Belum Mendengarkan Prinsip Itu, Yaitu 'Prinsip Kesejahteraan', Prinisip Tidak Akan Ada Kemiskinan Di Dalam Indonesia Merdeka'... Apakah Kita Mau Indonesia Merdeka Yang Kaum Kapitalisnya Merajalela, Ataukah Semua Rakyatnya Sejahtera, Yang Semua Orang Cukup Makan, Cukup Pakaian, Hidup Dalam Kesejahteraan, Merasa Dipangku Oleh Ibu Pertiwi Yang Cukup Memberi Sandang, Pangan Kepadanya". (Alam, 2000: 25)

Secara Konsep Ideologi Acap Kali Dipahami Dalam Arti Yang Berbeda. Satu Sisi Ideologi Sering Dicemooh Sebagai Sebuah Kesadaran Palsu, Tapi Ditakuti Layaknya Hantu. Sisi Lain Ideologi Berperan Sebagai Sebuah Dogma, Ketika Realitas Ternyata Tidaklah Sama Dengan Ideologi, Maka Realitas Tersebut Yang Harus Menyesuaikan Dengan Ideologi. Terkadanga Dirasakan Ideologi "Memperkosa" Realitas, Karena Kerap Kali Ideologi Diandaikan Lebih Riil Dari Realitas Itu Sendiri. Pada Lain Waktu, Ideologi Itu Dipuja Seperti Sebuah Keyakinan Yang Menyerupai Agama, Sehingga Penganutnya Rela Berkorban Untuk Memperjuangkan Ideologi Tersebut. (Putro, 2019: 10)

Sampai Hari Ini, Pancasila Tetap Menjadi Ideologi Kehidupan Berbangsa Dan Bernegara Di Indonesia. Meski Banyak Sekali Pihak-Pihak Yang Ingin Mengganti Pancasila Sebagai Ideologi, Misalnya Partai Komunis Indonesia, Yang Dalam Beberapa Kali Kesempatan Mencoba Memasukkan Paham Komunis Di Indonesia. Pascareformasi Beberapa Pihak Juga Ingin Mengganti Pancasila Dengan Ideologi Lain. Beberapa Peristiwa Peledakan Bom Yang Terjadi Di Indonesia, Dipercaya Sebagai Bagian Untuk Menggantikan Pancasila Sebagai Ideologi Negara-Bangsa Indonesia.

Pancasila Sebagai Suatu Ideologi Bangsa Dan Negara Indonesia, Pada Hakikatnya Diangkat Atau Berasal Dari Nilai-Nilai AdatIstiadat, Nilai-Nilai Kebudayaan Serta Nilai Religius Yang Terdapat Dalam Berbagai Pandangan Hukum Masyarakat Indonesia Sebelum Negara Ini Dibentuk. Artinya, Materi Pancasila Sebenarnya Berasal Dan Berakar Pada Pandangan Hidup Masyarakat Indonesia Itu Sendiri. Unsur-Unsur Tersebut Yang
Kemudian Dirumuskan Oleh Pendiri Negara Sehingga Lahirlah Pancasila Sebagai Dasar Negara Dan Menjadi Ideologi Bangsa Dan Negara Indonesia. (Kaelan, 2004: 110)

Pancasila Yang Nilai-Nilainya Diambil Atau Bersumber Pada Nilai-Nilai Budaya Bangsa Indonesia, Meminjam Istilah Yang Digunakan Oleh Margareth Mead, Ralp Linton Dan Abraham Kardiner Dalam Anthropology To Day, Disebut Sebagai National Character. Ralp Linton Lebih Senang Menyebutnya Dengan Peoples Character, Atau Dalam Suatu Negara Disebut Dengan National Identity. (Kaelan, 2004: 110); Sehingga Nilai-Nilai Kebudayaan Sekaligus Nilai Religius Yang Sudah Ada Pada Bangsa Indonesia, Untuk Kemudian Dibahas Serta Dirumuskan Oleh Founding Fathers Bangsa Indonesia, Untuk Selanjutnya Terjadi Suatu Konsensus Dijadikan Sebagai Dasar Hidup Bersama Bagi Seluruh Bangsa Indonesia. (Zabda, 2016: 111)

Wahono Mengatakan Bahwa Sejak Awal Pembentukannya, Pancasila Sebagai Ideologi Lahir Dari, Oleh Dan Untuk Bangsa Indonesia. Pancasila Merupakan Falsafah Dan Pandangan Hidup Bangsa Yang Secara Operasional Dijadikan Sebagai Bangsa Indonesia. Pancasila Merupakan Konsensus Politik Yang Menjanjikan Suatu Komitmen Untuk Bersatu Dalam Sikap Dan Pandangan Guna Mewujudkan Tujuan Nasional.

Nilai-Nilai Yang Terdapat Dalam SilaSila Pancasila Yang Merupakan Kesepakatan Pendiri Negara Ini Mewajibkan Seluruh Rakyat Indonesia Untuk Mengimplementasikannya Sesuai Dengan Situasi Dan Kondisi Dalam Kehidupan Sehari-Hari Serta Menghindari Perilaku Yang Bertentangan Dengan Nilai-Nilai Dasar Tersebut. Pancasila Sebagai Ideologi Terbuka Tentu Saja Memiliki Keterbukaan, Keluwesan Yang Mesti Diterima Serta Dilaksanakan Oleh Seluruh Golongan Yang Ada Di Indonesia Tanpa Terkecuali. Pancasila Sebagai Ideologi Nasional Juga Harus Mampu Memberikan Wawasan, Asas Dan Pedoman Normatif Bagi Seluruh Aspek Serta Dijabarkan Menjadi Norma Moral Dan Norma Hukum.

Pancasila Sebagai Ideologi Terbuka Menjadikan Nilai-Nilai Pancasila Sebenarnya Dapat Dikembangkan Sesuai Dengan Perubahan Zaman Ketika Saat Menjalani Kehidupan Berbangsa Dan Bernegara. Sifat Dinamis Pancasila Ini Sangat Dibutuhkan Untuk Menjaga Ketahanan Nasional Di Tengah Arus Perubahan Modern Yang Sangat Cepat Dan Massif. (Maharani, 2019: 280)

Ketahanan Nasional Tidak Akan Terlepas Dari Ketahanan Ideologi Pancasila. Ketahanan Nasional Yang Dalam Bahasa Inggris Dikenal Sebagai National Resilience, 
Dianggap Memiliki Definisi Yang Dinamik, Aktif, Dan Proaktif. Ketahanan Nasional Adalah Kondisi Dinamik Suatu Bangsa Yang Berisi Keuletan Dan Ketangguhan. (Maharani, Dkk., 2019: 280). Ketahanan Nasional Dalam Perspektif Suryohadiprojo Merupakan Kondisi Dinamik Suatu Bangsa Yang Berisi Keuletan Dan Ketangguhan. Ketahanan Nasional Juga Berisi Kemampuan Untuk Mengembangkan Kekuatan Nasional Dalam Menghadapi Segala Tantangan, Ancaman, Hambatan, Dan Gangguan Baik Itu Yang Berasal Dari Dalam Maupun Luar Negeri, Baik Secara Langsung Maupun Tidak Langsung, Membahayakan Integritas, Identitas, Kelangsungan Hidup Bangsa Dan Negara, Serta Perjuangan Mengejar Tujuan Dan Cita-Cita Nasionalnya.

Pancasila Sebagai Suatu Ideologi Bagi Bangsa Indonesia, Sebab Pancasila Merupakan Suatu Kepercayaan Yang Dianggap SatuSatunya Ideologi Yang Paling Tepat Dalam Menjalani Sistem Kenegaraan Republik Indonesia. Pancasila Merupakan Science of Ideas Dari Para Founding Father Semisal Ir. Soekarno, Mr. Soepomo, M. Yamin Serta Kh. Bagus Hadikusumo Serta Beberapa Tokoh Nasional Yang Turut Serta Dalam Menyusun Ideologi Yang Akhirnya Dinamakan Pancasila. Pancasila Merupakan Lima Dasar Yang Telah Disepakati Oleh Bangsa Indonesia Melalui Founding Father Yang Harus Dilaksanakan Oleh Bangsa Indonesia Dalam Sistem Kehidupan Sosial Maupun Sistem Kenegaraan Yang Meliputi:

1. Ketuhanan Yang Maha Esa,

2. Kemanusiaan Yang Adil Dan Beradab,

3. Persatuan Indonesia,

4. Kerakyatan Yang Dipimpin Oleh Hikmat Kebijaksanaan Dalam Permusyawaratan/Perwakilan,

5. Keadilan Sosial Bagi Seluruh Rakyat Indonesia.

Berdasarkan Argumentasi Di Atas, Maka Sebenarnya Pemahaman Masyarakat Terhadap Pancasila Sebagai Ideologi Seharusnya Menjadi Perhatian Yang Sangat Besar Oleh Segenap Bangsa Indonesia. Hal Ini Terjadi Karena Dalam Beberapa Tahun Kebelakang Terutama Pascareformasi, Nilai-Nilai Yang Terdapat Dalam Sila-Sila Itu Terasa Semakin Jauh. Perubahan Tersebut Bukan Hanya Karena Dinamisnya Kehidupan Masyarakat, Namun Lebih Jauh Adalah Berkembangnya Pemahaman Tentang Adanya Ideologi Lain, Yang Diyakini Mampu Memberikan Harapan Yang Lebih Baik Daripada Ideologi Pancasila.

Bebasnya Saluran Informasi Teknologi Dirasakan Dampaknya Oleh Segenap Lapisan Masyarakat. Nilai-Nilai Ketuhanan Yang Seharusnya Menjadi Titik Tolak Dalam
Berbagai Aturan Perundang-Undangan Nampaknya Diabaikan Karena Dianggap Kuno Dan Tak Lagi Relevan Untuk Dipertahankan. Nilai-Nilai Persatuan Yang Semestinya Menjadi Dasar Kehidupan Berbangsa Dan Bernegara, Kini Tercabik-Cabik Kelangsungannya Apalagi Selama Dan Setelah Berlangsungnya Pemilihan Umum Baik Presiden, Gubernur/Wakil Gubernur, Dan Bupati/Walikota. Terpecahnya Masyarakat Dalam Bermacam Kelompok, Sesungguhnya Merupakan Ancaman Terhadap Persatuan Dan Kesatuan Bangsa. Apabila Masyarakat Sudah Terpecah, Maka Disintegrasi Bangsa Akan Semakin Mengemuka, Dan Potensi Untuk Hilangnya Negara Kesatuan Republik Indonesia Semakin Nyata. Hal Tersebut Tentu Saja Bertentangan Dengan Cita-Cita Para Pendiri Bangsa. Oleh Karena Itu, Pemahaman Terhadap Pancasila Agar Terus Ditingkatkan Melalui Pembelajaran Pendidikan Pancasila Sebagaimana Dahulu Pernah Ada Mata Pelajaran Pendidikan Moral Pancasila Pada Tahun 1970-1990-An.

Urgensi Pendidikan Pancasila Sebagai Upaya Membumikan Nilai-Nilai Pancasila Untuk Membangkitkan Rasa Nasionalisme

Pasca Refromasi Pada Medio Mei

1998, Perubahan Drastis Terjadi Dalam SendiSendi Kehidupan Bangsa Indonesia. Masyarakat Ketika Ada Dalam Euforia Tanpa Batas, Sehingga Diberbagai Pelosok Nusantara, Banyak Yang Memaknai Reformasi Sebagai Era Yang Bebas Dari Nilai Apapun. Reformasi Dimaknai Sebagai Suatu Era Yang Tak Perlu Lagi Memakai Nilai-Nilai Yang Berasal Dari Orde Baru Yang Dianggap Penuh Dengan Masalah Dan Seluruh Jejaknya Harus Dihapus Dalam Sejarah Kehidupan Bangsa Indonesia.

Salah Satu Keputusan Kontroversi Saat Itu Adalah Dihapusnya Pelajaran Pendidikan Moral Pancasila Yang Selama Puluhan Tahun Diajarkan Dari Bangku Sekolah Dasar Hingga Perguruan Tinggi. Keputusan Tersebut Ternyata Disesali Oleh Semua Pihak 15 Tahun Kemudian Pascareformasi Karena Melihat Jauhnya Masyarakat Dari Nilai-Nilai Yang Tertanam Dalam Pancasila. Dekadensi Moral Yang Dialami Tidak Hanya Oleh Masyarakat Tapi Juga Terjadi Pada Kalangan Elit Pemerintah. Perilaku Koruptif Yang Semakin Lama Jumlahnya Semakin Membengkak Setiap Tahunnya, Mengindikasikan Ada Sesuatu Yang Salah Dalam Perjalanan Kehidupan Berbangsa Dan Bernegara.

Pancasila Mulai Kehilangan Ruhnya. Pelajar Dan Mahasiswa Banyak Yang Tidak Hapal Sila-Sila Yang Terdapat Dalam Pancasila, Sehingga Jangankan Untuk Mengimplementasikan Nilai-Nilainya, Sila- 
Silanya Saja Tidak Tahu Berapa Jumlah Dan Apa Isi Dan Maknanya. Oleh Sebab Itu Sangat Riskan Mengharapkan Munculnya Rasa Nasionalisme Pemuda Harapan Bangsa Untuk Membela Bangsa Dan Negaranya Pada Masa Depan, Jika Ideologi Bangsanya Sendiri Saja Tidak Diketahuinya.

Berdasarkan Fakta-Fakta Tersebut Di Atas, Maka Memang Diperlukan Pendidikan Karakter Untuk Mengembalikan Identitas Jati Diri Bangsa Serta Untuk Memupuk Rasa Nasionalisme Generasi Muda Bangsa Secara Khusus. Pendidikan Karakter Menurut Dianti Harus Dimulai Dengan Proses Penanaman Pengetahuan Tentang Hal-Hal Yang Baik Kemudian Diaplikasika Dalam Bentuk Sikap Dalam Pergaulan Hidup Sehari-Hari. (2014: 62). Pendidikan Pancasila Dan Kewarganegaraan Dipandang Penting Untuk Mengembalikan Nilai-Nilai Moral Dan Nasionalisme Yang Mulai Luntur Dalam Diri Sebagian Orang-Orang Indonesia.

Pasal 35 Ayat (3) Undang-Undang Republik Indonesia Nomor 12 Tahun 2012 Tentang Pendidikan Tinggi, Yang Dimaksud Dengan Mata Kuliah Pendidikan Pancasila Adalah Pendidikan Untuk Memberikan Pemahaman Dan Penghayatan Kepada Mahasiswa Mengenai Ideologi Bangsa Indonesia. Berdasarkan Landasan Yuridis Tersebut, Direktorat Jenderal Pendidikan Tinggi Mengembangkan Esensi Materi Pendidikan Pancasila Yang Terdiri Dari:
a. Pengantar Perkuliahan Pendidikan Pancasila
b. Pancasila Dalam Kajian Sejarah Bangsa Indonesia
c. Pancasila Sebagai Dasar Negara
d. Pancasila Sebagai Ideologi Negara
e. Pancasila Sebagai Sistem Filsafat
f. Pancasila Sebagai Sistem Etika
g. Pendekatan Pembelajaran Dasar Nilai Pengembangan Ilmu.
Urgensi Dan Tujuan Pendidikan Pancasila Dan Kewargangeraan Adalah Untuk Membentuk Warga Negara Indonesia Yang Baik Berlandaskan Pancasila Yaitu Membentuk Warga Negara Yang Religius, Berkemanusiaan Dan Berkeadaban, Memiliki Jiwa Nasionalisme, Bertanggungjawab Dan Adil Terhadap Lingkungan Sosialnya, Membentuk Kecakapan Partisipatif Yang Bermutu Serta Demokratis. (Desti, 2017: 126)

Agar Lebih Efektif Ketika Diajarkan, Maka Direkomendasikan Pendekatan Pembelajaran Pada Mata Kuliah Pendidikan Pancasila Dengan Berpusat Kepada Mahasiswa (Student Ctered Learning). Hal Ini Dilakukan Dalam Rangka Untuk Memahami Serta Menghayati Nilai-Nilai Pancasila Sebagai Etika,
Filsafat Negara, Maupun Ideologi Bangsa Secara Scientific. Tujuan Akhirnya Adalah Agar Nilai-Nilai Pancasila Terinternalisasi Sehingga Menjadi Guiding Principles Atau Kaidah Yang Dapat Menuntun Mahasiswa Saat Mengembangkan Jiwa Profesionalisme Sesuai Dengan Jurusan Atau Program Studi Yang Diambilnya. Diharapkan Setelah Mempelajari Pendidikan Pancasila, Akan Lahir Mahasiswa Yang Menjadi Insan Profesional Berjiwa Pancasila Dalam Kehidupan Bermasyarakat Dan Bernegara. Pendidikan Pancasila Diharapkan Juga Untuk Dapat Membentengi Serta Menjawab Tantangan Berbagai Perubahan Dimasa Akan Datang.

Era Orde Baru Yang Berkuasa Selama 32 Tahun, Dengan Menjadikan Pancasila Sebagai Komoditas Politik, Sehingga Masyarakat Dibatasi Gerak Langkahnya Untuk Berbicara Dan Beraktivitas Secara Politik, Ketika Reformasi Terjadi Tahun 1998, Maka Sejak Saat Itu Pula Pancasila Dianggap Sebagai “Barang Antik', Sehingga Layak Untuk Masuk Museum Sejarah. Pancasila Semakin Tidak Eksis Dalam Kehidupan Masyarakat. (Siswanto, 2017: 56)

Kehilangan Tempat Dari Masyarakat Negaranya, Pancasila Seperti Tidak Punya Tuan. Oleh Karena Itu Diperlukan Formula Khusus, Agar Pancasila Tidak Lagi Termarginalkan Oleh Masyarakat Indonesia, Sehingga Nilai-Nilai Moral Yang Tertanam Dalam Sila-Sila Pancasila Dapat Kembali Dihayati Oleh Rakyat Indonesia.

Eksistensi Pendidikan Pancasila Merupakan Sesuatu Yang Sifatnya Sangat Esensial Bagi Program Studi Di Sekolah Maupun Perguruan Tinggi. Menjadi Suatu Kewajaran Bahkan Keharusan Apabila Pancasila Disebarluaskan Secara Masif, Melalui Mata Kuliah Pendidikan Pancasila Di Sekolah Maupun Perguruan Tinggi. Riyanto Mengatakan Bahwa Pendidikan Pancasila Khususnya Di Perguruan Tinggi Suatu Keniscayaan Karena Mahasiswa Adalah Agen Perubahan Serta Intelektual Muda Di Masa Depan Sebagai Pemegang Tongkat Estafet Kepemimpinan Bangsa Dalam Berbagai Lembaga Negara Baik Pusat Maupun Daerah, Serta Lembaga-Lembaga Bisnis Lainnya.

Perlunya Pendidikan Pancasila Dalam Setiap Jenjang Pendidikan Di Indonesia Salah Satunya Agar Pengaruh Arus Globalisasi Yang Terjadi Saat Ini Diseluruh Dunia, Dapat Diminimalisir Pengaruhnya Di Indonesia. Globalisasi Yang Ada Ternyata Tidak Hanya Berdampak Positif, Namun Juga Berdampak Negatif, Yaitu:

a) Pergeseran Nilai 
Sesuatu Yang Baru (Nilai, Teknologi, Budaya, Dan Lainnya) Dari Asing Secara Tidak Otomatis Dapat Diintegrasikan Ke Dalam Kondisi Individu Atau Masyarakat Yang Menerimanya.

b) Pertentangan Nilai Masuknya Nilai-Nilai Baru Dan Asing Yang Tidak Sejalan Atau Bahkan Betentangan Dengan Nilai-Nilai Luhur Dari Pandangan Hidup Masyarakat.

c) Perubahan Gaya Hidup (Life Style)

d) Berkurangnya Kedaulatan Negara Pemerintah Dalam Hal Ini Harus Mengakui Dan Bekerja Di Suatu Lingkungan Dimana Sebagian Besar Penyelesaian Masalah Harus Dirumuskan Dengan Memerhatikan Dunia Global. (Asmaroini, 2017: 57)

Visi Pendidikan Pancasila Yaitu Terwujudnya Kepribadian Civitas Akademika Yang Besumber Pada Nilai-Nilai Pancasila. Misi Pendidikan Pancasila Yaitu Mengembangkan Potensi Akademik Peserta Didik Atau Misi Psikopedagogis, Menyiapkan Peserta Didik Untuk Hidup Dan Berprikehidupan Dalam Masyarakat, Bangsa Dan Negara Atau Misi Psikososial, Membangun Budaya Yang Berpancasila Sebagai Salah Satu Determinan Kehidupan Atau Misi Sosiokultura, Mengkaji Dan Mengembangkan Pendidikan Pancasila Sebagai Sistem Pengetahuan Terintegrasi Atau Disiplin Ilmu Sintetik Sebagai Misi Akademik.

Selain Kompetensi-Kompetensi Yang Disebutkan Di Atas, Kompetensi Yang Diharapkan Dari Pendidikan Pancasila Yaitu Agar Mahasiswa Menjadi Warga Negara Yang Memiliki Daya Saing, Berdisiplin, Berpartisipasi Aktif Dalam Membangun Kehidupan Yang Damai Berdasarkan Sistem Nilai Pancasila.

Tujuan Materi Pancasila Dalam Ramburambu Pendidikan Kepribadian Mengarahkan Pada Moral Yang Diharapkan Terwujud Dalam Kehidupan Sehari-Hari Yaitu Perilaku Yang Memancarkan Iman Dan Takwa Kepada Tuhan Yang Maha Esa Dalam Masyarakat Yang Terdiri Atas Berbagai Golongan Agama, Kebudayaan Dan Beraneka Ragam Kepentingan Memantapkan Kepribadian Mahasiswa Agar Secara Konsiseten Mampu Mewujudkan Nilai-Nilai Dasar Pancasila, Rasa Kebangsaan Dan Cinta Tanah Air Dalam Menguasai, Menerapkan Dan Mengembangkan Ilmu Pengetahuan Teknologi Dan Seni Dengan Rasa Tanggung Jawab Dan Bermoral.

\section{KESIMPULAN}

Berdasarkan Pembahasan Di Atas, Maka Diperoleh Kesimpulan Bahwa Mata Pelajaran Atau Mata Kuliah Pendidikan Pancasila Harus Kembali Diajarkan, Mengingat Nilai-Nilai Etika Yang Menjadi Ciri Khas Bangsa Indonesia Semakin Lama Semakin Jauh. Pancasila Yang Mengajarkan Nilai-Nilai Moral Yang Terdapat Dalam Sila-Silanya, Saat Ini Semakin Termarginalkan, Sehingga Muncul Kekhawatiran Di Masa Depan Nilai-Nilai Pancasila Tidak Lagi Dikenal Oleh Anak-Anak Indonesia. Padahal Pancasila Merupakan Ideologi Yang Mesti Diketahui Dan Diterapkan Oleh Seluruh Bangsa Indonesia. Pendidikan Pancasila Yang Diajarkan Di Sekolah Maupun Perguruan Tinggi Harus Dimodifikasi Yang Disesuaikan Dengan Metode Kekinian, Sehingga Kemasannya Menjadi Lebih Menarik.

\section{DAFTAR PUSTAKA}

Alam,Wawan Tunggul (Ed.), 2000, Bung Karni Menggali Pancasila, Gramedia, Jakarta.

Asmaroini, Ambiro Puji, "Menjaga Eksistensi Pancasila Dan Penerapannya Bagi Masyarakat Di Era Globalisasi”, Dalam Jpk: Jurnal Pancasila Dan Kewarganegaraan, Vol. 2, No. 1, Januari 2017.

Brata, Ida Bagus, Ida Bagus Nyoman Wartha, "Lahirnya Pancasila Sebagai Pemersatu Bangsa Indonesia", Dalam Jurnal Santiaji Pendidikan, Vol. 1, No. 7, Januari 2017.

Desti, Tri, "Peran Pendidikan Pancasila Dan Kewarganegaraan Dalam Menanamkan Karakter Kebangsaan Pada Anak Berkebutuhan Khusus Di Sekolah Inklusi". Prosiding Konferensi Nasional Kewarganegaraan Iii, Pada Tanggal 11 November 2017, Di Universitas Ahmad Dahlan, Yogyakarta.

Dianti, Puspa, "Integrasi Pendidikan Karakter Dalam Pembentukan Pendidikan Kewarganegaraan Untuk Mengembangkan Karakter Siswa", Dalam Jurnal Pendidikan Ilmu Sosial, Vol. 23, No. 1, 2014.

Doeroso, Bambang, 1989, Dasar Dan Konsep Pendidikan Moral Pancasila, Semarang: Cv. Aneka Ilmu, 1989, Cet. I., Hlm. 123-124.

Ferry Irawan Febriansyah, 2016, Keadilan Berdasarkan Pancasila, Yogyakarta: Cv. Busi Utama, Cet. I.

Kaelan, 2004, Pendidikan Pancasila, Paradigma, Yogyakarta. 
Kassab, Hanna Samir, 2016, The Power Of Emotion In Politics, Philosophy, And Ideology, Palgrave Macmillan, Basingstoke, New Yorke.

Maharani, Septiana Dwi Putri, Dkk., "Indeks Ketahanan Ideologi Pancasila", Dalam Jurnal Ketahanan Nasional, Vol. 25, No. 2, Agustus 2019.

Marsudi, Subandi Al, 2008, Pancasila Dan Uud 1945 Dalam Paradigma Reformasi, Jakarta: Pt Rajagrafindo Persada.

Maulia, Siti Tiara, "Pemahaman Konsep NilaiNilai Pancasila Sebagai Ideologi Bangsa",

Https://Publikasiilmiah.Ums.Ac.Id/Bits tream/Handle/11617/10772/4\%20siti\% 20tiara\%20maulia.Pdf? Sequence $=1 \& I$ sallowed $=Y$, Diakses Tanggal 8 Februari 2020, Pukul 13.08 Wib.

Muladi, 2006, Pancasila Sebagai Dasar Pengembangan Ilmu Hukum Di Indonesia. Makalah Disampaikan Sebagai Pidato Utama Pada Seminar Nasional Dalam Rangkan Dies Natalis Ke-40 Universitas Pancasila Jakarta, 7 Desember 2006.

Putro, Widodo Dwi, "Pancasila Di Era Paska Ideologi", Dalam Veritas Et Justitia: Jurnal Ilmu Hukum, Vol. 5, No. 1, 2019, Fakultas Hukum Universitas Katolik Parahyangan, Bandung.

Riyanto, Astim, "Pancasila Dasar Negara Indonesia", Dalam Jurnal Hukum Dan Pembangunan, Tahun Ke-37, Nomor 3, Juli-September 2007.

Rosyadi, Imron, "Pemikiran Munawir Sjadzali Tentang Pancasila Sebagai Dasar Negara Ri”, Dalam Jurnal Ishraqi, Volume Iv, Nomor 2, Juli-Desember 2008.

Siswanto, "Transformasi Pancasila Dan Identitas Keindonesiaan", Dalam Jurnal Penelitian Politik, Vol. 14, No.
1, Juni 2017, Lembaga Ilmu Pengetahuan Indonesia, Jakarta.

Supriyatno, Arie, "Pancasila Sebagai Ideologi Terbuka", Dalam Edukasi: Jurnal Penelitian \& Artikel Pendidikan, Vol. 3, No. 6, Juli 2011.

Suryatni, Luh, "Pancasila Sebagai Ideologi Negara Dan Hak Asasi Manusia Dalam Menjaga Keutuhan Negara Kesatuan Republik Indonesia", Dalam Jurnal Ilmiah Hukum Dirgantara, Fakultas Hukum Universitas Suryadarma, Vol. 5, No. 1, 2014.

Suryohadiprojo, Sayidiman, "Ketahanan Nasional Indonesia", Dalam Jurnal Ketahanan Nasional, Vol. 2, No. 1, Tahun 1997, Melalui Https://Jurnal.Ugm.Ac.Id/Jkn/Article/V iew/19163/12424, Diakses Tanggal 9 Februari 2020, Pukul 15.13. Wib.

Suseno, Franz Magnis, 1992, Filsafat Sebagai Ilmu Kritis, Kanisius, Jakarta.

Sutrisno, "Peran Ideologi Pancasila Dalam Perkembangan Konstitusi Dan Sistem Hukum Di Indonesia", Dalam Jpk: Jurnal Pancasila Dan Kewarganegaraan, Vol. 1, No. 1, Juli 2016.

Warsito, "Internalisasi Nilai-Nilai Luhur Pancasila Dalam Mata Kuliah Pendidikan Pancasila Di Perguruan Tinggi", Melalui Https://Www.Researchgate.Net/Public ation/331481079_Internalisasi_NilaiNilai_Luhur_Pancasila_Dalam_Mata_ Kuliah_Pendidikan_Pancasila_Di_Perg uruan_Tinggi, Diakses Tanggal 7 Februari 2020, Pukul 08.25 Wib.

Zabda, Sutan Syahrir, "Aktualisasi Nilai-Nilai Pancasila Sebagai Dasar Falsafah Negara Dan Implementasinya Dalam Pembangunan Karakter Bangsa", Dalam Jurnal Pendidikan Ilmu Sosial, Vol. 26, No. 2, Desember 2016. 